UDC $547.567 .5+547.792 .1+547.574 .3$

\author{
B. Murashevych ${ }^{a}$, Y. Trush ${ }^{a}$, N. Toropin ${ }^{a}$, K. Burmistrov ${ }^{a}$, T. Vergun ${ }^{b}$
}

\title{
SYNTHESIS OF AMIDRAZONES BY THE REACTION BETWEEN QUINONE ARENALAZINES AND AMMONIA
}

\author{
${ }^{a}$ Ukrainian State University of Chemical Technology, Dnipro, Ukraine \\ ${ }^{b}$ Dnipro Scientific Research Forensic Centre of the Ministry of Internal Affairs of Ukraine, Dnipro, \\ Ukraine
}

\begin{abstract}
The reactions between quinone arenalazines or their chlorine derivatives and ammonia were investigated. It was shown that these reactions lead to the formation of amidrazones of 1,4-benzoquinone. The optimal preparative conditions for this reaction were determined. The reaction scheme involves the 1,8 -addition of ammonia similar to the addition of mono-, dialkylamines and arylamines described earlier. The direct product of the addition instantly undergoes oxidation by air oxygen and cannot be separated in a pure form. The yields of the synthesized amidrazones depend on oxidation-reduction potential of initial quinone imine and grow with an increase in its magnitude. The structure of the obtained products was confirmed by the data of NMR spectroscopy and liquid chromatographymass spectrometry. It was determined that amidrazones of 1,4-benzoquinone exist mainly in quinoid tautomeric form and the amount of other tautomers is negligible. The synthesized substances can be likely used as precursors of high range of heterocyclic compounds.
\end{abstract}

Keywords: amidrazones, quinone imines, quinone arenalazines, ammonia, 1,2,4-triazoles, 1,8-addition.

DOI: $10.32434 / 0321-4095-2019-123-2-12-17$

\section{Introduction}

Recently, we have described a convenient method for the synthesis of 1,2,4-triazoles derivatives, which consists in interaction between the benzylidenehydrazono-2,5-cyclohexadiene-1,2-ones (quinone arenalazines) (I) or their chlorine derivatives (II) with monoalkylamines and further functionalization of its heterocyclic products [1-3] (Scheme 1).

It is obvious that the 1,8 -addition of amine is a first stage of this reaction if using quinone imines (I) as the substrates. We described the corresponding scheme for dialkylamines [4] and arylamines [5]. The prepared amidrazone of 1,4-benzoquinone spontaneously undergoes cyclization to form 1,2,4- triazole ring. In case of chlorine derivatives (II), similar amidrazones are formed as a result of nucleophilic substitution of the halogen atom by the aminogroup. This reaction mechanism is proposed in ref. [6].

Although 1,2,4-triazoles synthesis from hydrazones derivatives, particularly amidrazones, in general is considered as a developed trend in organic chemistry [7], our method has a number of significant advantages over those known before. In particular, unlike the methods described in [8,9], it does not require the use of exclusive organometallic catalysts, toxic carbon (II) oxide or the necessary separation of the intermediate products. Besides, our latest investigations have shown that new 5-mercapto-

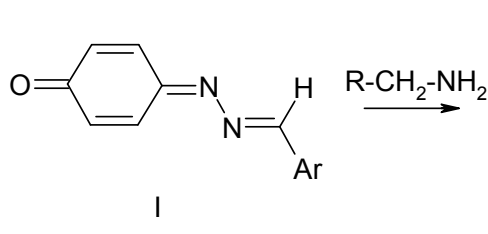<smiles>[R]CNC(=O)CN</smiles>

Scheme 1

(C) B. Murashevych, Y. Trush, N. Toropin, K. Burmistrov, T. Vergun, 2019

B. Murashevych, Y. Trush, N. Toropin, K. Burmistrov, T. Vergun 
1,2,4-triazole derivatives can be also obtained by this method if using ammonium rhodanide instead of monoalkylamines [10].

All the synthesized compounds are potentially bioactive and likely can be used as the active components for antifungal [11], antidiabetic [12], antitubercular [13] and other kinds of medications. So, further investigations of synthetic potential of 1,8 -addition to quinone imines are of great practical interest.

The purpose of this research is the investigation of the reactions between quinone arenalazines and ammonia and the determination of their applicability for the heterocyclic compounds synthesis.

\section{Theory}

Quinone imines, being electron-deficient compounds, readily interact with nucleophiles to form basically the corresponding aminophenols with substitute in ortho- or meta-positions to the carbon atom which is linked with the quinogenic hydroxy group. Reactions between quinone imines and amines are very diverse and can lead to both quinoid products of addition and heterocyclic products, carbazoles, for example [14]. The transimination is very common here, too [15]. The insertion of amino group into quinoid cycle can be also reached by indirect methods, for example, by substitution of halogen atom. But, the reactions of quinone imines with ammonia are practically not described and lead to the formation of multicomponent mixture of unidentified substances, probably because of their simultaneous passing by different directions.

Previous investigations allow us to suggest that quinone arenalazines will interact with ammonia according to the 1,8-addition scheme with the formation of the amidrazones (IV) (Scheme 2). Products (IV) are very promising, because the products of their interaction with carbonyl compounds, e.g. aldehydes, can undergo cyclization described in ref. [6], and it will allow expanding significantly the variety of heterocyclic compounds synthesized earlier (Scheme 3).

\section{Results and discussion}

As expected, the main products of the reaction between quinone arenalazines (I a-c) and ammonia turned out to be the amidrazones of 1,4benzoquinone (IV a-c). The same products were obtained as a result of the interaction of ammonia with the chlorine derivatives (II a-c), and besides such method leads to the higher yields of amidrazones (IV) re-counting on initial quinone imine (I). Thus, reaction of quinone arenalazines with ammonia can be represented by the next Scheme 3 .

From a preparative viewpoint, the addition of a large excess of ammonia in water solution to a dichloroethane solution of substrate (I) or (II) is optimal.

Together with amidrazones (IV), impurities of

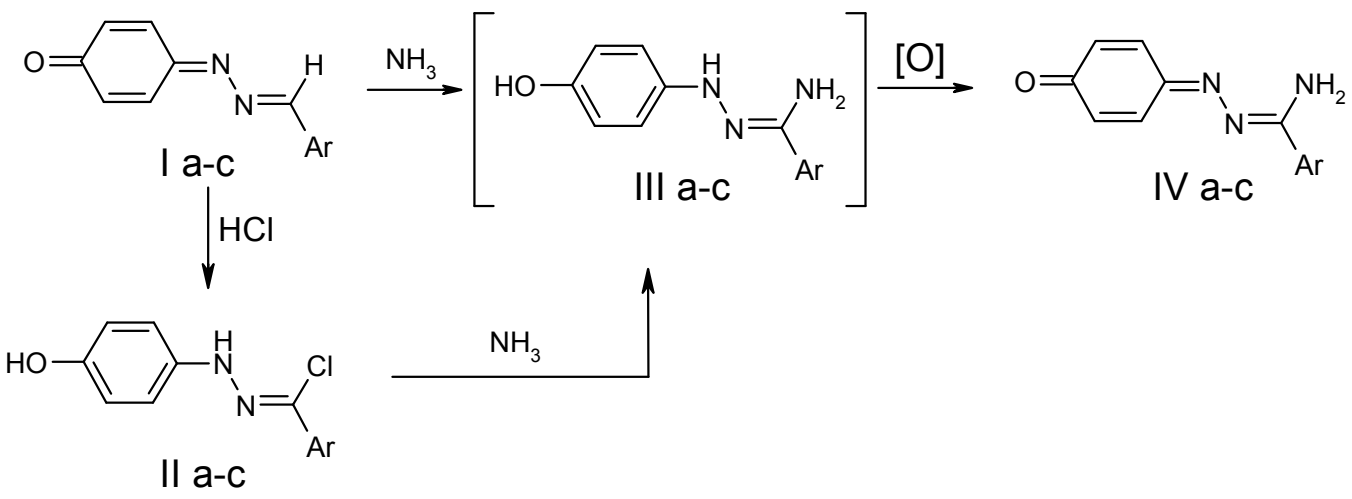

$$
\mathrm{Ar}=\mathrm{p}-\mathrm{NO}_{2}-\mathrm{C}_{6} \mathrm{H}_{4}-(\mathrm{a}), \mathrm{p}-\mathrm{Br}-\mathrm{C}_{6} \mathrm{H}_{4}(\mathrm{~b}), \mathrm{p}-\mathrm{Cl}-\mathrm{C}_{6} \mathrm{H}_{4}-(\mathrm{c})
$$

Scheme 2

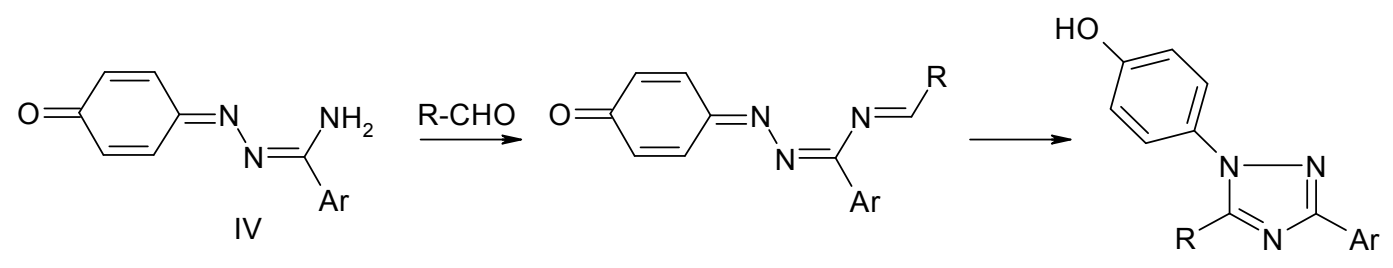

Scheme 3 
the arylaldehydes have been found in reaction mixture by thin-layer chromatography. Apparently, these compounds are usually formed as a result of partial hydrolysis of the initial quinone imine molecule. Also, the presence of unidentified colorless substance has been noted. Though it has not been separated from the mixture in a pure form, it is highly likely the product of the condensation of arylaldehydes with amidrazones (IV). The separation of the intermediate 1,8 -addition product (III) is impossible, too, because of its instantaneous oxidation by air oxygen, which is caused by decreasing the oxidation-reduction potential of such a system as a result of the amino group insertion. The above scheme has been confirmed with visual observations of the reaction mixture color: when adding ammonia to the solution of $(I a, b)$, which has a typical for quinoid systems yellow coloration, it instantly became colorless but was turning yellow again with the course of time.

In case of direct interaction of ammonia with the quinone imine (I), the yield of the amidrazone (IV a) is significantly higher (about $45 \%$ ) than that

高
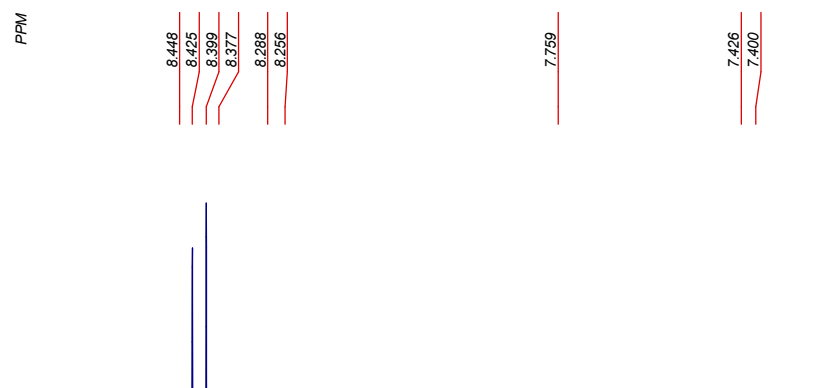

of amidrazones (IV b, c) (about 25\%). This can be explained by a higher oxidation-reduction potential of this substance and its lower tendency to hydrolysis.

The structure of the synthesized products has been proved by NMR ${ }^{1} \mathrm{H}$ spectroscopy and chromato-mass spectrometry data. The characteristic NMR ${ }^{1} \mathrm{H}$ spectrum of the amidrazone (IV a) is shown in Figure.

This spectrum reveals a signals of pseudo-ABsystems of para-substituted phenyl and a typical of such systems set of quinoid cycle protons signals which consists of two doublets caused by Z,Eizomerisation around quinoid $\mathrm{C}=\mathrm{N}$-bond. Also, a broad singlet of amino group protons can be observed near 7.8 p.p.m. The spectrum structure also shows that amidrazones (IV) exist predominantly in tautomeric form A, and the content of tautomers B and $\mathrm{C}$ is negligible (Scheme 4).

Thus, we showed that the reaction between quinone arenalazines and ammonia follows 1,8addition scheme with the formation of amidrazones of quinone, which can be precursors for a wide range

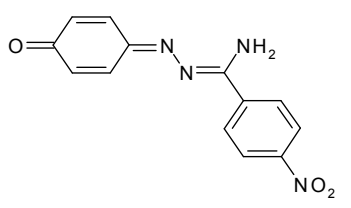

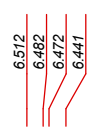

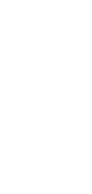

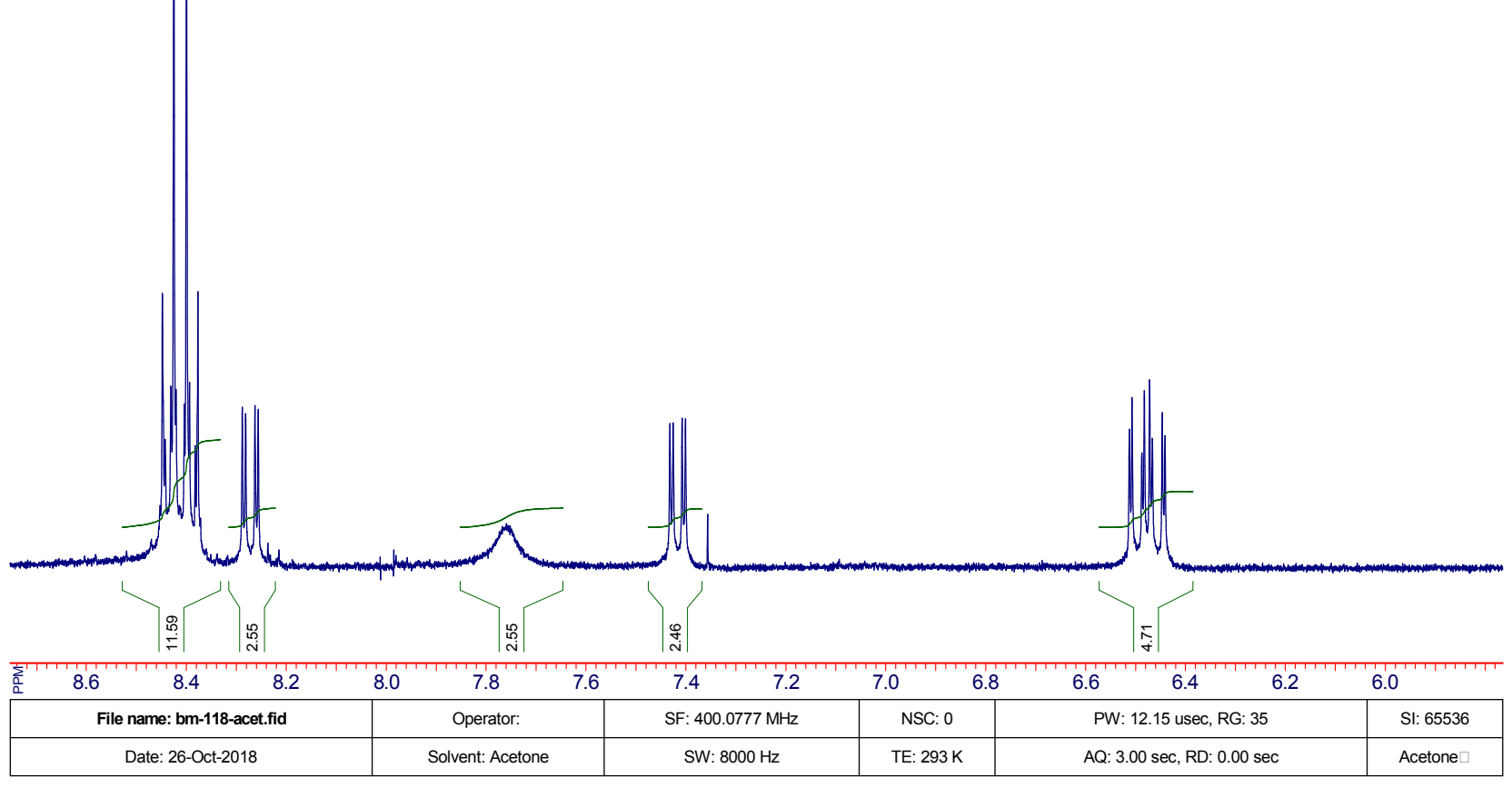

NMR ${ }^{1} \mathrm{H}$ spectrum of amidrazone (IV a) 


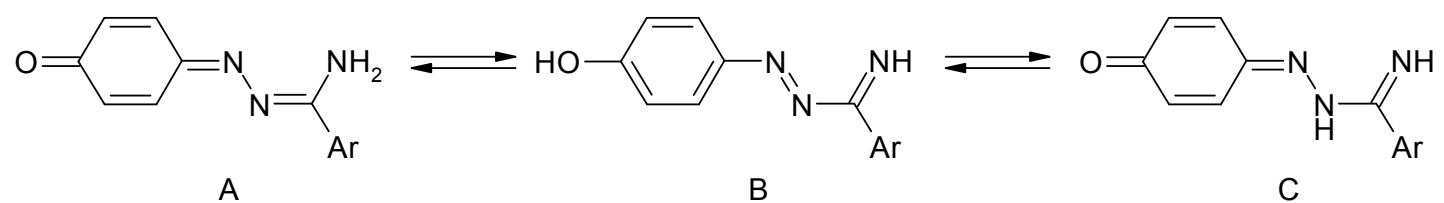

Scheme 4

of heterocyclic compounds.

\section{Experimental}

Synthetic methods of the initial compounds (I) and (II) were described elsewhere [6]. For the express control of the reaction fullness and for the qualitative analysis of the reaction mixture, thinlayer chromatography on Merck Kieselgel $60 \mathrm{~F}_{254}$ plates has been used with 1,2-dichloroetane or composition dichloroethane:propane-2-ole in proportion 9:1 as eluent. NMR ${ }^{1} \mathrm{H}$ spectra have been recorded using Jemini 2000 radiospectrometer operating at frequency $400 \mathrm{MHz}$, internal standard TMS, with DMSO- $\mathrm{d}_{6}, \mathrm{CDCl}_{3}$ or $\left(\mathrm{CH}_{3}\right)_{2} \mathrm{CO}-\mathrm{d}_{6}$ as solvents. Chromatography-mass spectra have been recorded by means of AGILENT 1100 liquid chromatograph with UV-detector, G1956B massdetector and Altech 3300 ELS detector.

\section{Method 1}

The portion of quinone imine (I) (ca. $4 \mathrm{mmol}$ ) was solved in 100-120 $\mathrm{cm}^{3}$ of 1,2-dichloroethane at heating and $20 \mathrm{~cm}^{3}$ of $22 \%$ ammonia water solution was added. The solution was intensively stirred and left overnight. Then, $200 \mathrm{~cm}^{3}$ of water was added. The reaction mixture was intensively shaken, the water layer was decantated, and this operation was repeated 3-4 times. The organic layer was separated and evaporated using a rotary evaporator. The formed crystals were repeatedly washed with hexane and dried. The yields were as follows: $48 \%$ (IVa), $28 \%$ (IVb) and 25\% (IVc).

\section{Method 2}

The portion of quinone imine (I) (ca. $4 \mathrm{mmol}$ ) was solved in 100-120 $\mathrm{cm}^{3}$ of 1,2-dichloroethane at heating and $10 \mathrm{~cm}^{3}$ of $30 \%$ water solution of hydrogen chloride was added. The reaction mixture was intensively stirred for 1 hour, then $200 \mathrm{~cm}^{3}$ of water was added. The mixture was intensively shaken, the water layer was decantated and this operation was repeated 3-4 times to thoroughly remove hydrogen chloride. Then organic layer was separated and 20 $\mathrm{cm}^{3}$ of $22 \%$ ammonia water solution was added. All further actions were similar to those described in Method 1. The yields were as follows: $62 \%$ (IVa), $42 \%(\mathrm{IVb})$ and $37 \%$ (IVc).

Physico-chemical properties and spectral characteristics of the synthesized compounds

$\mathrm{N}$-[( $\alpha$-amino(4-nitrobenzylidene]hydrazono- 2,5-cyclohexadiene-1-one (IVa): brown crystals, m.p. $201-203^{\circ} \mathrm{C}$ (with decomposition). NMR ${ }^{1} \mathrm{H}$ spectrum (solvent $\left.\left(\mathrm{CH}_{3}\right)_{2} \mathrm{CO}-\mathrm{d}_{6}\right): 8.436 \mathrm{~d}(2 \mathrm{H}, \mathrm{J}=9.2 \mathrm{~Hz})$, $8.390 \mathrm{~d}(2 \mathrm{H}, \mathbf{J}=9.2 \mathrm{~Hz}), 8.272 \mathrm{~d}(1 \mathrm{H}, \mathbf{J}=9.7 \mathrm{~Hz})$, $7.769 \mathrm{~s}(2 \mathrm{H}), 7.416 \mathrm{~d}(1 \mathrm{H}, \mathrm{J}=10.1 \mathrm{~Hz}), 6.499 \mathrm{~d}$ $(1 \mathrm{H}, \mathrm{J}=9.7 \mathrm{~Hz}), 6.453 \mathrm{~d}(1 \mathrm{H}, \mathrm{J}=10.1)$.

$\mathrm{N}$-[( $\alpha$-amino(4-bromobenzylidene]hydrazono2,5-cyclohexadiene-1-one (IVb): brown crystals, m.p. $163-165^{\circ} \mathrm{C}$ (with decomposition). NMR ${ }^{1} \mathrm{H}$ spectrum $\left(\right.$ solvent DMSO-d $\left.\mathrm{d}_{6}\right): 8.402 \mathrm{~s}(2 \mathrm{H}), 8,163 \mathrm{~d} .(1 \mathrm{H}$, $\mathrm{J}=10.2 \mathrm{~Hz}), 8.083 \mathrm{~d}(2 \mathrm{H}, \mathrm{J}=8.3 \mathrm{~Hz}), 7.748 \mathrm{~d}(2 \mathrm{H}$, $\mathrm{J}=8.3 \mathrm{~Hz}), 7.453 \mathrm{~d}(1 \mathrm{H}, \mathrm{J}=10.1 \mathrm{~Hz}), 6.510 \mathrm{~d}(1 \mathrm{H}$, $\mathrm{J}=9.7 \mathrm{~Hz}), 6.447 \mathrm{~d}(1 \mathrm{H}, \mathrm{J}=9.8 \mathrm{~Hz})$.

$\mathrm{N}-[(\alpha$-amino(4-chlorobenzylidene $]$ hydrazono2,5-cyclohexadiene-1-one (IVc): brown crystals, m.p. $158-160^{\circ} \mathrm{C}$ (with decomposition). NMR ${ }^{1} \mathrm{H}$ spectrum (solvent $\left.\mathrm{CDCl}_{3}\right): 8.226 \mathrm{~d}(1 \mathrm{H}, \mathrm{J}=10.3 \mathrm{~Hz}), 7.913 \mathrm{~d}$ $(2 \mathrm{H}, \mathrm{J}=8.7 \mathrm{~Hz}), 7.486 \mathrm{~d}(2 \mathrm{H}, \mathrm{J}=8.7 \mathrm{~Hz}), 7.386 \mathrm{~d}$ $(1 \mathrm{H}, \mathrm{J}=9.8 \mathrm{~Hz}), 6.579 \mathrm{~d}(1 \mathrm{H}, \mathrm{J}=10.1 \mathrm{~Hz}), 6.524 \mathrm{~d}$ $(1 \mathrm{H}, \mathrm{J}=10.3 \mathrm{~Hz})$.

\section{REFERENCES}

1. Unusual reaction of 4-[2-(4-nitrobenzylidene) hydrazinylidene]-cyclohexa-2,5-dienone with propan-1-amine / B. Murashevych, K. Shreiber, N. Toropin, K. Burmistrov // Russ. J. Org. Chem. - 2014. - Vol.50. - No. 3. - P.452-453.

2. Мурашевич Б.В., Шрейбер К.А., Лебедь О.С. Синтез 1-(4-гидроксифенил)-3-(4-нитрофенил)-5-алкил-1,2,4-триазолов // Известия высших учебных заведений. Химия и химическая технология. - 2015. - Т.58. - № 4. - С.7-9.

3. Reactions of (1-(4hydroxyphenyl)3-(4-nitrophenyl)-5ethyl-1,2,4-triazole with electrophilic agents / K.A. Shreiber, B.V. Murashevych, K.S. Burmistrov, N.V. Toropin // Voprosy Khimii i Khimicheskoi Tekhnologii. - 2014. - No. 1. - P.28-31.

4. Мурашевич Б.В., Бурмистров К.С., Торопин Н.В. Взаимодействие аренальазинов 1,4-бензохинона с вторичными алифатическими аминами // Вопр. химии и хим. технологии. - 2011. - № 1. - С.14-18.

5. Murashevych B., Toropin N., Burmistrov K. Reaction of 4-[2-(arylmethylidene) hydrazinylidene] cyclohexa-2,5-dienones with aromatic amines // Russ. J. Org. Chem. - 2013. - Vol.49. - No. 10. - P.1466-1469.

6. Изучение механизма реакции аренальазинов хинонов с первичными алкиламинами / Мурашевич Б.В., Шрейбер К.А., Михеенко В.М. и др. // Вопросы химии и хим. 
технологии. - 2015. - № 6. - С.13-18.

7. Current developments in the syntheses of 1,2,4-triazole compounds / H.-Z. Zhang, G.L.V. Damu, G.-X.Cai, C.-H. Zhou // Curr. Org. Chem. - 2014. - Vol.18. - P.359-406.

8. Cyclization of 1,2,4-triazenes to 1,2,4-triazoles using oxidizing reagents $-\mathrm{NaClO}, \mathrm{Ca}(\mathrm{ClO})_{2}$, Dess-Martin periodinane and Ley's TPAP/NMO / K. Paulvannan, R. Hale, D. Sedehi, T. Chen // Tetrahedron. - 2001. - Vol.57. - No. 48. - P.96779682.

9. Su W., Yang D., Li J. Novel process for synthesis of 1,2,4-triazoles: ytterbium triflate-catalyzed cyclization of hydrazonyl chlorides with nitriles // Synth. Commun. - 2005. Vol.35. - No. 11. - P.1435-1440.

10. Synthesis of 1-(4-hydroxyphenyl)-3-aryl-5-mercapto1,2,4-triazoles from arenalazine quinones / N. Toropin, Y. Trush, B. Murashevych, K. Burmistrov // Voprosy Khimii i Khimicheskoi Tekhnologii. - 2018. - No. 2. - P.46-50.

11. Peyton L.R., Gallagher S., Hashemzadeh M. Triazole antifungals: a review // Drugs Today. - 2015. - Vol.51. No. 12. - P.705-718.

12. Zhou C.H., Wang Y. Recent researches in triazole compounds as medicinal drugs // Curr. Med. Chem. - 2012. Vol.19. - No. 2. - P.239-280.

13. Triazole: a promising antitubercular agent / Keri R.S., Patil S.A., Budagumpi S., Nagaraja B.M. // Chem. Biol. Drug. Des. - 2015. - Vol. 86. - No. 4 . - P.410-423.

14. Burmistrov K.S., Glukh A.I., Toropin N.V. Oxidative cyclization of N-p-tolyl-2,5-bis(p-tolylamino)-1,4-benzoquinone imine // Russ. J. Org. Chem. - 2005. - Vol.41. - P.944-945.

15. Transimination of quinone imines: a mechanism for embedding exogenous redox activity into the nucleosome / Wenjie Ye., Seneviratne U.I., Chao M.-W., Ravindra K.C., Wogan G.N., Tannenbaum S.R., Skipper P.L. // Chem. Res. Toxicol. - 2012. - Vol.25. - No. 12. - P.2627-2629.

Received 15.11.2018

\section{СИНТЕЗ АМІДРАЗОНІВ РЕАКЦІЕЮ АРЕНАЛЬАЗИНІВ ХIHOHIB 3 АМОНIAKOM}

\author{
Б. Мурашевич, Я. Труш, Н. Торопін, К. Бурмістров, Т. \\ Вергун
}

Досліджені реакції аренальазинів хінонів та їх хлорпохідних з амоніаком. Показано, що ці реакиії призводять до утворення амідразонів 1,4-бензохінону. Визначені оптимальні препаративні умови для цих реакцій. Механізм реакції полягає в 1,8-приєднанні амоніаку, як це було описано раніше для моно-, діалкіламінів та ариламінів. Продукт безпосереднього приєднання амоніаку миттєво окиснюється киснем повітря $і$ не може бути виділений в чистому вигляді. Виходи амідразонів залежать від окисно-відновного потенціалу вихідного хіноніміну та зростають з підвищенням його величини. Структуру одержаних продуктів доведено даними ЯМР спектроскопії та хромато-масс спектрометрії. Доведено, що амідразони хінону існують переважно в хіноїдній таутомерній формі, а вміст інших таутомерів зневажливо мале. Синтезовані сполуки вірогідно можуть застосовуватись в якості прекурсорів широкої низки гетероциклічних речовин.

Ключові слова: амідразони, хіноніміни, аренальазини хінону, амоніак, 1,2,4-триазоли, 1,8-приєднання.

\section{SYNTHESIS OF AMIDRAZONES BY THE REACTION BETWEEN QUINONE ARENALAZINES AND AMMONIA}

B. Murashevych a, ", Y. Trush a, N. Toropin a, K. Burmistrov ${ }^{a}, T$. Vergun ${ }^{b}$

a Ukrainian State University Of Chemical Technology, Dnipro, Ukraine

${ }^{b}$ Dnipro Scientific Research Forensic Centre of the Ministry of Internal Affairs of Ukraine, Dnipro, Ukraine

*e-mail: murashevych.b@gmail.com

The reactions between quinone arenalazines or their chlorine derivatives and ammonia were investigated. It was shown that these reactions lead to the formation of amidrazones of 1,4-benzoquinone. The optimal preparative conditions for this reaction were determined. The reaction scheme involves the 1,8-addition of ammonia similar to the addition of mono-, dialkylamines and arylamines described earlier. The direct product of the addition instantly undergoes oxidation by air oxygen and cannot be separated in a pure form. The yields of the synthesized amidrazones depend on oxidationreduction potential of initial quinone imine and grow with an increase in its magnitude. The structure of the obtained products was confirmed by the data of NMR spectroscopy and liquid chromatography-mass spectrometry. It was determined that amidrazones of 1,4-benzoquinone exist mainly in quinoid tautomeric form and the amount of other tautomers is negligible. The synthesized substances can be likely used as precursors of high range of heterocyclic compounds.

Keywords: amidrazones; quinone imines; quinone arenalazines; ammonia; 1,2,4-triazoles; 1,8-addition. 


\section{REFERENCES}

1. Murashevich B.V., Shreiber K.A., Toropin N.V., Burmistrov K.S. Unusual reaction of 4-[2-(4-nitrobenzylidene) hydrazinylidene]-cyclohexa-2,5-dienone with propan-1-amine. Russian Journal of Organic Chemistry, 2014, vol. 50, pp. 452-453.

2. Murashevych B.V, Shrejber K.A., Lebed O.S. Sintez 1(4-gidroksifenil)-3-(4-nitrofenil)-5-alkil-1,2,4-triazolov [Synthesis of 1-(4-hydroxyphenyl)-3-(4-nitrophenyl)-5-alkyl-1,2,4-triazoles]. Izvestiya Vysshikh Uchebnykh Zavedenii. Khimiya i Khimicheskaya Tekhnologiya, 2015, vol. 58, no. 4, pp. 7-9. (in Russian).

3. Shreiber K.A., Murashevych B.V., Burmistrov K.S., Toropin N.V. Reactions of (1-(4-hydroxyphenyl)3-(4nitrophenyl)-5-ethyl-1,2,4-triazole with electrophilic agents. Voprosy Khimii i Khimicheskoi Tekhnologii, 2014, no. 1, pp. 28-31.

4. Murashevich B., Toropin N., Burmistrov K. Vzaimodeistvie arenal'azinov 1,4-benzokhinona s vtorichnymi alifaticheskimi aminami [Interaction between quinone arenalazines and secondary aliphatic amines]. Voprosy Khimii i Khimicheskoi Tekhnologii, 2011, no. 1, pp. 14-18. (in Russian).

5. Murashevich B.V., Burmistrov K.S., Toropin N.V. Reaction of 4-[2-(arylmethylidene) hydrazinylidene] cyclohexa2,5-dienones with aromatic amines. Russian Journal of Organic Chemistry, 2013, vol. 49, pp. 1466-1469.

6. Murashevich B.V., Shreiber K.A., Miheenko V.M., Burmistrov K.S., Toropin N.V. Izuchenie mekhanizma reaktsii arenal'azinov khinonov s pervichnymi alkilaminami [Study of the mechanism of the reaction between quinones arenalazines and primary alkylamines]. Voprosy Khimii i Khimicheskoi Tekhnologii, 2015, no. 6, pp. 13-18. (in Russian).

7. Zhang H.-Z., Damu G.L.V., Cai G.-X., Zhou C.-H. Current developments in the syntheses of 1,2,4-triazole compounds. Current Organic Chemistry, 2014, vol. 18, pp. 359406.
8. Paulvannan K., Hale R., Sedehi D., Chen T. Cyclization of 1,2,4-triazenes to 1,2,4-triazoles using oxidizing reagents $\mathrm{NaClO}, \mathrm{Ca}(\mathrm{ClO})_{2}$, Dess-Martin periodinane and Ley's TPAP/NMO. Tetrahedron, 2001, vol. 57, pp. 9677-9682.

9. Su W., Yang D., Li J. Novel process for synthesis of 1,2,4-triazoles: ytterbium triflate-catalyzed cyclization of hydrazonyl chlorides with nitriles. Synthetic Communications, 2005, vol. 35 , pp. 1435-1440.

10. Toropin N.V., Trush Y.V., Murashevych B.V., Burmistrov K.S Synthesis of 1-(4-hydroxyphenyl)-3-aryl-5mercapto-1,2,4-triazoles from arenalazine quinones. Voprosy Khimii i Khimicheskoi Tekhnologii, 2018, no. 2, pp. 46-50.

11. Peyton L.R., Gallagher S., Hashemzadeh M. Triazole antifungals: a review. Drugs Today, 2015, vol. 51, pp. 705-718.

12. Zhou C.H., Wang Y. Recent researches in triazole compounds as medicinal drugs. Current Medicinal Chemistry, 2012, vol. 19 , pp. 239-280.

13. Keri R.S., Patil S.A., Budagumpi S., Nagaraja B.M. Triazole: a promising antitubercular agent. Chemical Biology \& Drug Design, 2015, vol. 86, pp. 410-423.

14. Burmistrov K.S., Glukh A.I., Toropin N.V. Oxidative cyclization of N-p-tolyl-2,5-bis(p-tolylamino)-1,4-benzoquinone imine. Russian Journal of Organic Chemistry, 2005, vol. 41, pp. 944-945.

15. Wenjie Ye., Seneviratne U.I., Chao M.-W., Ravindra K.C., Wogan G.N., Tannenbaum S.R., Skipper P.L. Transimination of quinone imines: a mechanism for embedding exogenous redox activity into the nucleosome. Chemical Research in Toxicology, 2012, vol. 25, pp. 2627-2629. 